\title{
Implementing basic e-learning tools into an undergraduate taxation curriculum
}

\author{
T. van Oordt and Ingrid Mulder \\ University of Pretoria, Department of Taxation, Pretoria, South Africa \\ ${ }^{*}$ Corresponding author: Ingrid Mulder can be contacted at: \\ ingrid.mulder@up.ac.za
}

\begin{abstract}
Purpose - Educators in the accounting discipline are faced with the challenge of finding innovative ways to accommodate the flexible learning styles of Millennial students, using "in classroom/contact time" effectively and decreasing transactional distance between students and educators in large classes. In an attempt to address these challenges, this paper aims to describe the implementation of basic e-learning tools (podcasts, vodcasts and voice-over-PowerPoint) as supplementary and substitutional tools in an undergraduate taxation curriculum. The tools were implemented as part of a student-centred approach to the facilitation of learning, embedded in the Blended Learning Theory. The paper reports on students' use and experience of various basic e-learning tools, as well as the impact of the use of these tools on student performance.

Design/methodology/approach - An action research methodology was followed, and data were collected by way of a voluntary, descriptive student survey and student class lists. A total of 387 students completed the survey.

Findings - Students appear to have access to devices and data to use e-learning tools. They perceive these tools as helpful study aids and prefer synchronous, substitutional tools. Use of the tools does not have a significant impact on performance; however, it does appear to have a positive impact on the learning environment and student engagement.

Originality/value - The results of the study may be of benefit to educators and curriculum designers who are responsible for reviewing and updating the content delivery methods of undergraduate taxation curricula in large classes with diverse student populations. These results add to the limited body of knowledge on the implementation of basic e-learning tools in a South African accounting education setting.
\end{abstract}

Keywords Accounting education, Millennials, Blended learning, E-learning tools, Podcasts, Student-Centred, Vodcasts, Voice-over-PowerPoint

\section{Introduction}

Understanding the learning preferences of students is an essential component in the implementation of pedagogies which will have the desired impact on student learning (Laurillard, 2002; Fink, 2003; Lai and Hong, 2015). The majority of students currently enrolled at contact higher education institutions form part of the generation referred to as the "Millennials" (Howe and Strauss, 1991). Millennials have different social characteristics, different ways of using information and constructing knowledge and

The research was funded by the University of Pretoria, Department of Education Innovation Scholarship of Teaching and Learning Grant. The researchers are grateful to colleagues who have reviewed the project in earlier stages and provided valuable feedback. 
different expectations about life and learning preferences (Bullen et al., 2001; Prensky, 2001), in contrast from the needs of those for whom the current education system was designed (Spector et al., 2014).

Participants in higher education and leaders in society across all disciplines see a need for institutions of higher education to provide educational programs that result in different and more significant kinds of learning (Fink, 2003). To create more significant kinds of learning, it is advocated that educators move away from the traditional teaching and learning model to a culture of facilitative learning and student-centredness that addresses the learning preferences of Millennials (McWilliam, 2008). A student-centred approach is described as progressive, where the educator acts as a guide to the education experience and students take on a more active role; and the teacher-centred approach is traditional, where the educator is the distributor of knowledge and the students are passive participants (Bennet, 1976; Leveson, 2004; Visser et al., 2006).

Accounting education literature in recent years has also emphasised the need to create significant learning experiences through following a student-centred approach to the facilitation of learning (Boritz and Carnaghan, 2003; McWilliam, 2008; Miller and Woods, 2000; Apostolou et al., 2013). Given that they are part of accounting educators, taxation educators have to address the expectations of different stakeholders (being professional bodies, employers and students) to equip taxation graduates for the world of work in thetwenty-first century (Miller and Woods, 2000; Hesketh, 2011; Guthrie et al., 2014; Bayerlein, 2015).

In a South African context, taxation educators must adhere to the requirements of professional bodies such as the South African Institute of Tax Professionals (SAIT) and the South African Institute of Chartered Accountants (SAICA). These professional bodies prescribe a large amount of technical and pervasive competencies, which higher education institutions need to incorporate into their curricula to gain accreditation or remain accredited with regard to their professional qualifications (SAICA, 2015; SAIT, 2015). Future employers also require graduates to have a high standard of technical and pervasive skills (Barac, 2009; Doman and Nienaber, 2012). Educators are responsible for accomplishing the task of meeting both groups of stakeholder requirements, as well as address the learning preferences of students, with limited "in class/contact time" to do so (Boritz and Carnaghan, 2003).

The limited "in class/contact time" has to be effectively used within the challenges of teaching large student groups, as is the case at many of the South African universities (Universum, 2014). The student group size at the university where this study was performed is in excess of 1,000 students, with an excess of 200 students per class. The number of students in a large class makes it difficult for the lecturer to communicate and interact personally with them (Gibbs and Jenkins, 1992). The amount of interaction between educators and students is referred to as transactional distance (Van Rooyen, 2010). The higher the interaction between students and educators on different communicative platforms, the less distance there would be between the students' and educators' pedagogical "transaction" (Bayerlein, 2014). Educators are faced with a consequent need to create a more effective platform of interaction with and among students than the traditional teacher-centred face-to-face interaction (Gibbs and Jenkins, 1992; Prinsloo and Van Rooyen, 2007; De Wet and Van Niekerk, 2001; Van Rooyen, 2010). 
The challenge for taxation educators to address the changing learning preferences of Millennial students, to use "in class/contact-time" as effectively as possible to meet the demands of professional bodies and future employers, and to decrease transactional distance in large classes, is the motivation for this study. These challenges could be addressed by following a student-centred approach to the facilitation of learning embedded in the Blended Learning Theory. The Blended Learning Theory has been selected as the conceptual framework for this study and encompasses the integration of classroom face-to-face learning experiences with online learning experiences using information and communication technology (ICT) (McCarthy, 2010; Garrison and Kanuka, 2004; Prinsloo and Van Rooyen, 2007; Spector et al., 2014).

Previous studies have highlighted the value of including a student-centred approach to the facilitation of learning, embedded in the Blended Learning Theory, into university curricula. However, despite higher education institutions' awareness of the call for change, there are a number of factors influencing the implementation of such changes. The mainstream teaching and learning methods in undergraduate taxation and accounting are still very much focused on a twentieth century environment (Boritz and Carnaghan, 2003; McWilliam, 2008; Miller and Woods, 2000; Apostolou et al., 2013).

The factors inhibiting change could be uncertainty as to how the Blended Learning Theory can be practically applied, how students in a South African context use and experience the tools and whether the move to a blended learning environment has an actual impact upon student performance (Spector et al., 2014; Graham et al., 2013). The results of this study may therefore be of benefit to educators and curriculum designers who are responsible for reviewing and updating the content delivery methods in undergraduate taxation curricula, taking into account a theoretical as well as a practical approach. The results may be specifically relevant for educators teaching large classes with a diverse student population. The study was specifically structured to be a helpful classroom tool for educators to be able to design and implement the tools in their own settings.

The study aims to achieve the following two research objectives:

(1) to determine how students use and experience basic e-learning tools implemented into the undergraduate taxation curriculum; and

(2) to determine whether the use of basic e-learning tools has an impact on student performance.

To reach the research objectives, an action research methodology embedded in the Blended Learning Theory was followed to design and incorporate three different basic e-learning tools (podcasts, voice-over-PowerPoint and vodcasts) into an undergraduate taxation curriculum of a large student group (1,048 students) at a South African university. The tools were incorporated at different stages of the students' learning process, some as a revision tool (supplementary) and others as class preparation tools (substitutional) (Vogele and Gard, 2006). Qualitative and quantitative data were collected by way of a voluntary, descriptive student survey and student class lists.

This paper begins with a literature review that serves as background to the need for incorporating blended learning embedded in a student-centred approach, to facilitate learning into an undergraduate taxation curriculum. This is followed by a description of the action research design to address the research objectives as stated above and an 
analysis of the data obtained. The paper concludes with a summary of the findings and a discussion of limitations and directions for future research.

\section{Literature review}

The literature review commences with an explanation of the learning preferences of Millennials, followed by a discussion of implementing a student-centred approach to the facilitation of learning, to have the desired impact upon student learning. After an exploration of the challenges faced by accounting educators, the Blended Learning Theory is argued as a possible method to address the identified challenges and move to a student-centred approach. The literature review concludes with a review of the incorporation of basic e-learning tools in other settings and the outcomes of previous research on the topic.

\section{Understanding the learning preferences of students}

The average age of students currently enrolled at contact higher education institutions in South Africa is 25.1 years, born in the 1990s (Universum, 2014). According to Generational Theory, these students belong to the Millennial Generation, also referred to as the Net Generation, Digital Natives, or Generation Y (Howe and Strauss, 1991). Although there are some conflicting opinions as to the specific years, the majority of generational theorists claim that the Millennial Generation includes individuals born after 1982 and before 2004 (Bullen et al., 2001; Sandeen, 2008; Howe and Strauss, 1991).

There are two schools of thought on the characteristics of the Millennial Generation, specifically in terms of their use of ICTs in education (Spector et al., 2014). One school of thought claims that the learning preferences of the current students in higher education differ significantly from those of other generations, as Millennials have been using the tools of the digital age for as long as they can remember, for both leisure and educational purposes (Prensky, 2001; Laurillard, 2002; Spector et al., 2014). Millennials may favour education by means of wireless devices and expect customisation, personalisation and flexibility when it comes to learning opportunities. They also expect $24 / 7$ access to instruction and student services, and educators are advised to follow student trends and to change pedagogies, to keep up with student expectations of flexible learning (Sandeen, 2008; Prensky, 2001).

There are some studies, however, which contradict the notion that there are significant differences in the behavioural characteristics, including the use of ICT, between the Millennials and other generations. These studies warn educators not to make educational strategy decisions based upon the assumption that all learners from this specific generation have homogeneous characteristics that vary significantly from other generations (Bullen et al., 2001; Gros et al.,2012). Educators should not assume that students' competence in using technology in their everyday lives necessarily implies that they can transfer those same skills to learning activities. Pedagogy and teaching models will have a greater influence on the use of technology in learning than the mere fact that students are part of the Millennial Generation (Gros et al., 2012; Lai and Hong, 2015; USA Department of Education, 2009).

Authors who are cautious about the widespread acceptance that Millennials have different learning preferences than other generations, however, also agree that the use of ICT by Millennials is a certainty and a reality that educators must take into consideration (Bullen et al., 2001; Gros et al., 2012). There is an agreement that the 
Millennials live in a world which is trademarked by flexible learning, a variety of learning delivery methods and easy access to digital media and electronic resources (Lai and Hong, 2015; Spector et al., 2014; USA Department of Education, 2009). Educators at higher education institutions should take cognisance of the consequent changes in learning preferences of Millennials and acknowledge the importance of ICT in enhancing the quality of teaching and learning through appropriate pedagogical methods (Lai and Hong, 2015).

\section{A student-centred approach to the facilitation of learning}

To address the changing learning preferences of students, educational researchers have advocated that educators should move away from the traditional teaching approach to a student-centred approach to facilitate learning (Slabbert et al., 2009; Bennet, 1976; Leveson, 2004; Visser et al., 2006). A student-centred approach to the facilitation of learning aims to move away from a traditional approach of the transfer of knowledge to an approach where the needs of students as active participants in the learning process are addressed (Fink, 2003; Slabbert et al., 2009).

In line with the universal call to move to a student-centred approach to the facilitation of learning, South African taxation educators are also experiencing pressure to be innovative in their education strategies (De Wet and Van Niekerk, 2001; Barac, 2009; Hesketh, 2011). The increased pressure can be attributed to the fact that the Millennial students prefer flexible learning; different stakeholders require different sets of skills from taxation graduates and educators have limited "in class/contact time" to equip graduates, and large student classes increase transactional distance between students and educators (Doman and Nienaber, 2012; Garrison and Kanuka, 2004; Guthrie et al., 2014; Bayerlein, 2014).

The undergraduate taxation curriculum at accredited universities is largely influenced by the curricula based upon competency frameworks, as prescribed by the professional bodies, articulating into professional qualifications. The main professional bodies in South Africa that impact taxation education are the SAICA, the SAIT, the South African Institute of Professional Accountants and the Association of Chartered Certified Accountants South Africa. The competency frameworks as prescribed by these major professional bodies are obtained throughout a student's university education, as well as during post-graduation traineeships.

Accredited qualifications through the above-mentioned professional bodies cannot be obtained without meeting the prescribed competencies of the professional body. Numerous studies in accounting and taxation education however have identified and investigated an expectation gap between the competencies which employers and professional bodies seek, and the competencies which are held by university graduates. Most of these studies agree that accounting and taxation educators are mainly following a teaching approach that does not lead to developing the graduate attributes demanded by the profession (Barac, 2009; Coetzee and Oberholzer, 2009; De Lange et al., 2006; Dixon et al., 2010; Gammie et al., 2002; Howieson, 2003; Kermis and Kermis, 2010; McCarthy and McCarthy, 2006; Steinbank, 2010; Bayerlein, 2015).

The process of accreditation can have a negative impact upon taxation academy through exerting different mechanisms of influence (De Villiers and Venter, 2010; De Wet and Van Niekerk, 2001). The effect of these mechanisms leads to teaching with a technical focus without links to the social implications, and one only has to consider the 
vast body of knowledge prescribed by professional bodies, to conclude that this group of stakeholders favour technical skills (De Villiers and Venter, 2010). Within the traditional paradigm, students are trained to apply an impressive number of narrow computational rules to a given set of numbers. In their attempt to cover every computational rule that might affect taxpayers, educators often neglect to relate the tax aspects of a transaction to its accounting, financial or economic consequences (Jones and Duncan, 1995; Hite and Hasseldine, 2001; Bayerlein, 2015).

Educators therefore have to find innovative ways to utilise "in class/contact time" as effectively as possible to address the challenges as stated above. Content and content delivery are two major components of the educational curriculum (Fink, 2003). Due to the accreditation requirements of professional bodies, taxation educators have limited control over "content", as this component is prescribed by the professional bodies. The "content delivery" component is, however, within the educators' realm of control. The way in which educators facilitate learning should be reconsidered. Instead of merely "imparting knowledge", educators should, as part of their professional development, utilise learning theories in order to facilitate learning of the competencies proposed by professional bodies. Incorporating a student-centred approach entails integrating skills-based strategies of facilitating learning such as constructivist learning (Von Glasersfeld, 2001), self-regulated learning (Slabbert et al., 2009), collaborative learning (Johnson and Johnson, 1990); experiential learning (Kolb and Kolb, 2005) and blended learning (Garrison and Kanuka, 2004).

For the purposes of this study, the Blended Learning Theory has been selected as a conceptual framework to create a student-centred approach to the facilitation of learning, due to the advocated advantages of this learning theory as discussed in the next section.

\section{Blended learning (information and communication technology in curriculum) as the conceptual framework}

In its simplest form, blended learning is about integrating face-to-face learning experiences with online learning experiences (Garrison and Kanuka, 2004). It is an educational strategy that effectively integrates the strengths of both components, and it is not merely adding the one component, online learning, to the already dominant other, face-to-face learning (Wong et al., 2014). Each blended learning environment is fundamentally redesigned and reconceptualised in terms of the teaching and learning dynamic (e.g. discipline, developmental level and resources). Introducing technology into the curriculum can improve the quality of education (Talebian et al., 2014). However, the educational effectiveness of ICT depends upon how these technologies are used and for what purposes they are used (Talebian et al., 2014, Weil et al., 2014; USA Department of Education, 2009).

Garrison and Kanuka (2004) reviewed a number of studies dealing with ICT integration, and they concluded that student performance either improved or remained the same after being exposed to a blended learning environment. Blended learning has been found to promote student-centred learning, decrease transactional distance between educators and students and to encourage wider student participation with the benefit of flexible learning, variety and adaptability (Aliotta et al., 2008; Chan and Lee, 2005; Weil et al., 2014; Dickfos et al., 2014; Wong et al., 2014; USA Department of Education, 2009; Bayerlein, 2015). 
Graham et al. (2013) compiled the following framework to explain the concept of blended learning.

Although educators may be aware of the advocated benefits of including ICT in the curriculum, research has indicated that educators experience discomfort and a lack of competence for effective pedagogical use and integration of ICT in the curriculum. Educators are also not sure how students use and experience these tools, and whether going through the effort of implementing these tools will have an effect upon student performance (Lai and Hong, 2015; Spector et al., 2014; Prinsloo and Van Rooyen, 2007). This paper aims to assist educators to address the above uncertainties.

\section{The use of basic e-learning tools}

There are many tools that an educator can choose from to incorporate technology into the curriculum, to create a blended learning approach. Examples of these tools include the use of podcasts, vodcasts and voice-over-PowerPoint (Graham et al., 2013). The term podcasting, was coined in 2004 and resulted from a combination of the words "broadcasting" and "iPod" (Tynan and Colban, 2006). A podcast is an asynchronous tool, as it is a voice only with no visual presentation (Heilesen, 2010). A distinction is made between three categories of podcasts, namely, administrative podcasts (e.g. general information, guides), special lecture series (guest lectures, commencement lectures, etc.) and classroom podcasts (anything involving curriculum). Classroom podcasts can once again be divided into three sub-categories - substitutional (e.g. documenting or substituting classroom teaching), supplementary (e.g. providing summaries of classroom teaching) and creative (e.g. production by learners) (Vogele and Gard, 2006).

Vodcasts are podcasts with video content (Spector et al., 2014). These tools are referred to as synchronous tools, being the simultaneous playback of audio and video data streams (Griffin et al., 2009).

PowerPoint presentations are a common means of delivering lectures, and many educators have taken the option of podcasting audio recordings of their lectures, either recorded "live" or in the comfort of their offices, in addition to supplying the PowerPoint file online to their students (Griffin et al., 2009). This is also a synchronous tool with video and audio elements.

Studies on the educational use of e-learning tools concluded that when measuring learner performance only, academic indicators are weak that the basic e-learning tools are efficient (USA Department of Education, 2009). No studies however have indicated that the incorporation of these tools has a negative impact upon learning. Although these studies do not specifically conclude an increase in learner performance, learners often indicate that e-learning tools have a positive impact upon their learning environment and provide a variety and meet the demand for flexible learning, even if they do not improve their performance (Heilesen, 2010; Graham et al., 2013; Garrison and Kanuka, 2004).

The aforementioned studies were all conducted at higher education institutions in developed countries. There exists little research on the use, experience and impact upon performance of basic e-learning tools as a content delivery method to facilitate learning in a blended learning environment in developing countries such as South Africa (Mugwanya et al., 2011). 


\section{Synthesis of the literature}

The universal call for innovation in education when training Millennials, combined with the specific circumstances created by the needs of the different stakeholders in the South African taxation education environment, challenge South African taxation educators to use "in class/contact-time" as effectively as possible. One of the ways in which educators can create a student-centred approach to the facilitation of learning is to incorporate the Blended Learning Theory into the curriculum delivery method. The advantages of the Blended Learning Theory can possibly be achieved by implementing basic e-learning supplementary and substitutional tools. The next section describes the research method to implement basic e-learning tools into the undergraduate taxation curriculum.

\section{Research method}

Action research was considered to be the most appropriate research method to be followed in this empirical study, as it is a process that promotes professional development and evaluation of innovative teaching strategies, to solve problems encountered by educators (McNiff and Whitehead, 2006; Du Toit, 2009). Educational action research is one of the mainstreams of action research as a whole, and is a well-suited methodology for educational transformation in the twenty-first century (Somekh and Zeichner, 2009). It can be defined as any systematic inquiry conducted by researchers into the teaching and learning environment, to gather information on how their particular environment operates, how they teach and how well their students learn. It is a reflective process, conducted in the natural setting in which the problem is encountered, and it allows for inquiry and discussion to be components of the research. Information is gathered with the aim of gaining insights, developing reflective practice, effecting positive change in the educational environment and improving student learning (Somekh and Zeichner, 2009).

Action research is an overarching design that incorporates a cyclical process consisting of several iterations of action research cycles (McNiff and Whitehead, 2006). Two cycles were executed in this research project. The action research process is illustrated in Figure 1.

For the current study, a pilot study (first cycle) was performed in specific topics presented in 2014, which informed the design of the second action research cycle. The research process and data reported on in this study will mainly focus upon the second action research cycle.

\section{Phase 1: Planning, including problem and situation analysis}

In following, the action research methodology, a student-centred approach to facilitate learning, embedded in the Blended Learning Theory, was incorporated through the implementation of various basic e-learning tools into the curriculum of an undergraduate, introductory taxation course. This course is attended by 1,048 students majoring in accounting (towards the CA (SA) professional qualification) or financial sciences (towards other professional qualifications in the financial sciences). This is a year course, taken in the second year of a three-year degree programme, and focuses upon the basic principles of the tax framework, the taxation of individuals, estate duty and donations tax.

The researchers wanted to focus upon some of the challenges which they experienced within their environment, specifically to address the students' needs for flexible learning 


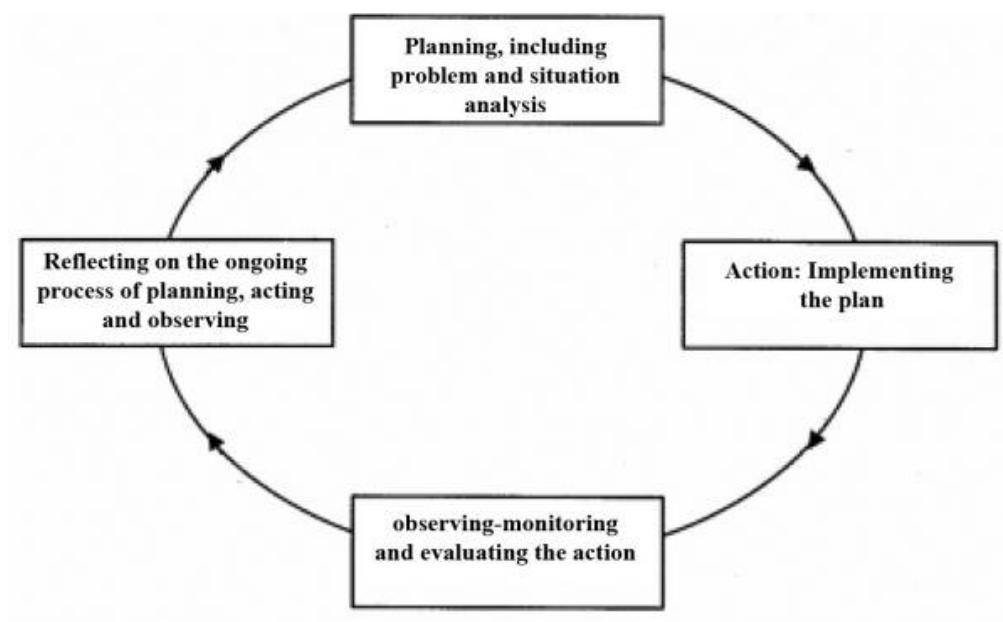

Source: McNiff and Whitehead (2006)

Figure 1.

(Lai and Hong, 2015; Spector et al., 2014), the effective use of "in class/contact time" (Hesketh, 2011; Howieson, 2003), as well decreasing the transactional distance between the students and the researchers (Prinsloo and Van Rooyen, 2007; Bayerlein, 2014). During the planning phase, the researchers made decisions regarding the tool type, length and timing of implementation as well as content.

\section{Tool type}

In the second cycle, three different e-learning tools were designed, namely, podcasts, vodcasts and voice-over-PowerPoint. The researchers aimed to follow a pedagogical approach to content delivery in creating tools which were basic enough to be created by educators with time, technological and budget constraints. The researchers considered these factors to have an influence upon the sustainability of the project, i.e. the ease of the design would impact implementation by other educators and across various different topics. The researchers investigated numerous programmes and acknowledge that there are various different applications available to create e-learning tools. However, the specific applications were selected as other programmes were found to be either too complex to master in the given time, too time-consuming in creating the tools or too expensive to set up with no available funding for the initiative. All tools created were made available as MP3 or MP4 files, to increase compatibility with as many devices as possible, in an attempt to increase student access.

\section{Length}

During the first cycle, students were asked what they considered to be the ideal length of a podcast (the tool implemented for revision). Their responses guided the design of the basic e-learning tools in the second cycle. In all, 9 per cent of the students indicated that the ideal podcast should be shorter than three minutes, 54 per cent indicated that it should be 3-6 min in length and 37 per cent indicated that it should be between 6 and 10 min in length. This is a response of 83 per cent of the students as the question was asked as part of the normal annual course feedback. 


\section{Language}

At the researchers' institution, training is presented in both English and Afrikaans. All basic e-learning tools were made available in English only. Feedback collected from the first cycle gave no indication that the Afrikaans students experienced difficulty in using the revision podcasts in a language other than the language of instruction (being Afrikaans); therefore, no adjustment was made to the language of e-learning tools in the second cycle.

\section{Timing of implementation}

Some of the tools were designed to be supplementary (pre-class preparation), and some were designed to be substitutional (revision tools) (Vogele and Gard, 2006). The researchers were keen to obtain student perceptions as to whether they use supplementary tools differently as opposed to the substitutional tools, and whether they experienced the one to be more beneficial for learning than the other.

The substitutional (revision) tools were made available to students after the content of a topic had been dealt with during "in class/contact time", but before an annual assessment was written. Students prepared for "in class/contact time" by means of reading the textbook and writing an online pre-test. "In class/contact time" focused upon covering the content theory and did not allow much time for application.

The supplementary tools were made available to students a week before the content of the topic was dealt with during "in class/contact time", as a means of preparing for the "in class/contact time". In line with the Blended Learning Theory (Figure 2), the face-to-face contact time was reduced by 25 per cent (students were relieved of the first of four weekly contact sessions), to allow students time to prepare for class by using the supplementary tools (Graham et al., 2013). Students were not required to write an online pre-test before attending the contact sessions. The reduced contact sessions were used in a different manner with a stronger focus upon practical application and less focus upon theory, due to the assumption that students had obtained a certain level of knowledge by using the tools. The researchers did not follow a complete flipped classroom approach, as some of the theory covered in the supplementary tools were revised during the contact sessions, but the focus had shifted. Students wrote a class test on the principles of the content theory, which was dealt with in the supplementary tools during the first contact session of the week. They were also free to use the supplementary tools for revision purposes during the following annual assessment.

\section{Content}

From the researchers' experience and from consultation with colleagues, topics were selected based upon their relevance within the curriculum and the level of difficulty

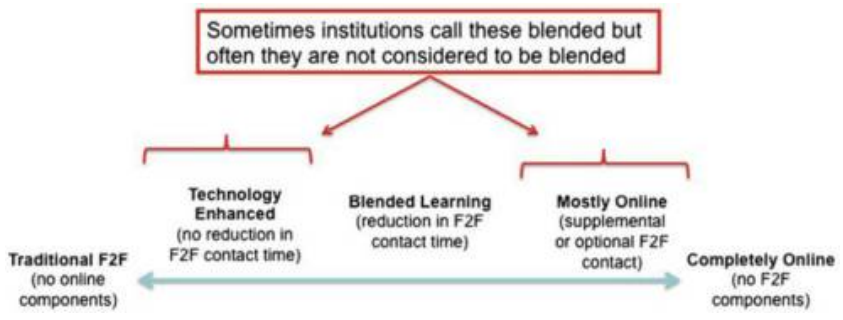

Figure 2. A framework for institutional adoption and implementation of blended learning in higher education 
students experienced with these topics. Due to the changing nature of taxation as a discipline, the researchers' main focus was not on specific rules or exceptions, but rather on the application of the general principle, to ensure re-use within the taxation curriculum.

Table I is a summary of the tools which were designed and implemented.

\section{Phase 2: Implementing the plan}

The e-learning tools were implemented at specific times as described above. The tools were reviewed by colleagues for technical accuracy as well as ease of use, before making the files available to the students on the learning management system. Students could download and save the files for repeated future use.

\section{Phase 3: Observing, monitoring and evaluating the action}

Student feedback and lecturer reflection were obtained after the pilot study/first action research cycle. The results were used to inform the design of the second action research cycle, which will be reported on in the next section.

An electronic, descriptive survey was chosen as the method of data collection, as it was the most cost-effective and easiest way of reaching the large number of students in the time available (Kelley et al., 2003). The university learning management system was used as the medium through which the survey was distributed. The survey consisted of both qualitative and quantitative questions. The data collected were from a sample of undergraduate taxation students who were exposed to the use of the basic e-learning tools as part of a blended learning environment. The survey was developed through a review of literature and refined after implementation in the first action research cycle, taking the responses into consideration. The survey was also internally validated through a peer review process. Completion of the survey was voluntary, and students were informed that their responses would be used anonymously. Data contained in student class lists (like demographics and marks) were also used.

The following section provides a descriptive analysis of the data obtained from the student sample, to determine the students' use and experience of the basic e-learning tools, as well as a hierarchical regression analysis to ascertain whether the use of the various basic e-learning tools had an impact upon student performance. The quantitative data were analysed using SPSS, and the qualitative data were analysed using Atlas Ti.

\section{Analysis of data}

The data analysis is shown in Tables II-VII. For ease of reference, these tables contain the following data:

- Table II: An analysis of the participant and group demographics. This analysis was used to address non-response bias, and the participant demographics were used as part of the regression analysis in Tables VI and VII.

- Table III: A description of the primary internet connections and devices used by participants to access e-learning tools.

- Table IV: A description of the participant's use, experience and preferences relating to e-learning tools. 


\section{Table I.}

\begin{tabular}{|c|c|c|c|c|}
\hline Tool & Revision podcasts & Preparation podcasts & Voice-over- $p$ & Vodcasts \\
\hline File format & MP3 file format ${ }^{\mathrm{a}}$ & MP3 file format & PowerPoint file format & MP4 file format \\
\hline Number of tools & Seven & Three & One & One \\
\hline Average length & $5.39 \mathrm{~min}$ & $4.6 \mathrm{~min}$ & $7.19 \mathrm{~min}$ & $11.03 \mathrm{~min}$ \\
\hline Average size & $7.96 \mathrm{MB}$ & $5.59 \mathrm{MB}$ & $17.9 \mathrm{MB}$ & $68.2 \mathrm{MB}$ \\
\hline Topic (one topic per file) & $\begin{array}{l}\text { Sections in the Income Tax Act: } \\
\text { 8(4)(a) and 11(0); 11(a); 11(c); } \\
11(\mathrm{e}) \text { and } 12 \mathrm{C} ; 13,13 \text { quin, 13sex; } \\
20 \text { and } 20 \mathrm{~A} ; 23 \mathrm{H}\end{array}$ & $\begin{array}{l}\text { Capital Gains Tax: Proceeds, base } \\
\text { cost, deceased and deceased } \\
\text { estates }\end{array}$ & $\begin{array}{l}\text { Capital Gains Tax: Exclusions } \\
\text { and rollovers }\end{array}$ & $\begin{array}{l}\text { Capital Gains Tax: Framework and } \\
\text { practical example calculation }\end{array}$ \\
\hline Design & $\begin{array}{l}\text { Windows sound recorder on } \\
\text { standard Microsoft software. } \\
\text { Output is a VMA file converted } \\
\text { to MP3 using a free } \\
\text { programme- Freemake Audio } \\
\text { Converter }\end{array}$ & $\begin{array}{l}\text { Windows sound recorder on } \\
\text { standard Microsoft software. } \\
\text { Output is a VMA file converted to } \\
\text { MP3 using a free programme-- } \\
\text { Freemake Audio Converter }\end{array}$ & $\begin{array}{l}\text { PowerPoint slide show, using a } \\
\text { normal laptop/desktop with a } \\
\text { microphone to record over each } \\
\text { slide }\end{array}$ & $\begin{array}{l}\text { Making use of the standard Apple } \\
\text { I-phone camera the Vodcast was } \\
\text { recorded and saved as file type } \\
\text { WMV. Using freeware downloaded } \\
\text { from the internet (Free WMV to } \\
\text { MP4 Converter) the file was } \\
\text { converted to MP4 and the size was } \\
\text { reduced }\end{array}$ \\
\hline Timing & $\begin{array}{l}\text { Made available to students after } \\
\text { they dealt with the topic in } \\
\text { class, before a test on the } \\
\text { specific topic. The test counted } \\
\text { towards the year mark of the } \\
\text { students }\end{array}$ & \multicolumn{3}{|c|}{$\begin{array}{l}\text { Made available to students a week before they dealt with the topic in class. Class test written on topic in class. The } \\
\text { test counted towards the year mark of the students }\end{array}$} \\
\hline
\end{tabular}

Note: ${ }^{a}$ Note that the revision podcasts were the only tool which formed part of the pilot project/first cycle. The implementation of podcasts as preparation tools as well as the development of the voice-over-PowerPoint and vodcasts were implemented in the second cycle, based upon the feedback received from students in the first cycle 
Table II.

\begin{tabular}{|c|c|c|c|c|}
\hline Variable & Variable explanation & Variable option & $\begin{array}{l}\text { Respondents } \\
n\end{array}$ & $\begin{array}{l}\text { Group } \\
\quad n\end{array}$ \\
\hline Number & \multirow{3}{*}{ Language of instruction at researchers' institution } & & $387(37 \%)$ & 1,048 \\
\hline \multirow[t]{2}{*}{ Language } & & Afrikaans & $90(23.3 \%)$ & $244(23.3 \%)$ \\
\hline & & English & $297(76.7 \%)$ & $804(76.7 \%)$ \\
\hline \multirow[t]{2}{*}{ Degree enrolment } & \multirow{2}{*}{$\begin{array}{l}\text { As discussed in Phase } 1 \text { of the research method, } \\
\text { these are the two major programmes that } \\
\text { students who take this module, are enrolled for }\end{array}$} & Accounting Sciences & $250(64.6 \%)$ & $565(54 \%)$ \\
\hline & & Financial Sciences & $137(35.4 \%)$ & $483(46 \%)$ \\
\hline \multirow[t]{2}{*}{ Age } & \multirow{2}{*}{$\begin{array}{l}\text { Represents Millennial generation (Universum, } \\
\text { 2014; Howe and Strauss, 1991) }\end{array}$} & Mean & 20.464 & 20.629 \\
\hline & & $\begin{array}{l}\% \text { of students } \\
\text { meeting definition of } \\
\text { Millennials }\end{array}$ & $99.7 \%$ & $99.9 \%$ \\
\hline \multirow[t]{2}{*}{ Repeat/First time } & \multirow{8}{*}{$\begin{array}{l}\text { Represents students who are either doing the } \\
\text { module for the first time or who are repeating the } \\
\text { module }\end{array}$} & First time & $371(95.9 \%)$ & $942(90 \%)$ \\
\hline & & Repeat & $16(4.1 \%)$ & $106(10 \%)$ \\
\hline \multirow[t]{4}{*}{ Race } & & African & $167(43.1 \%)$ & $482(46.0 \%)$ \\
\hline & & Coloured & $5(1.3 \%)$ & $23(2.2 \%)$ \\
\hline & & Indian & $34(8.8 \%)$ & $83(7.9 \%)$ \\
\hline & & White & $181(46.8 \%)$ & $460(43.9 \%)$ \\
\hline \multirow[t]{2}{*}{ Gender } & & Female & $271(70.0 \%)$ & $601(57.3 \%)$ \\
\hline & & Male & $116(30.0 \%)$ & $447(42.6 \%)$ \\
\hline
\end{tabular}


Table III. Primary internet connections and primary devices used by students to access basic elearning tools

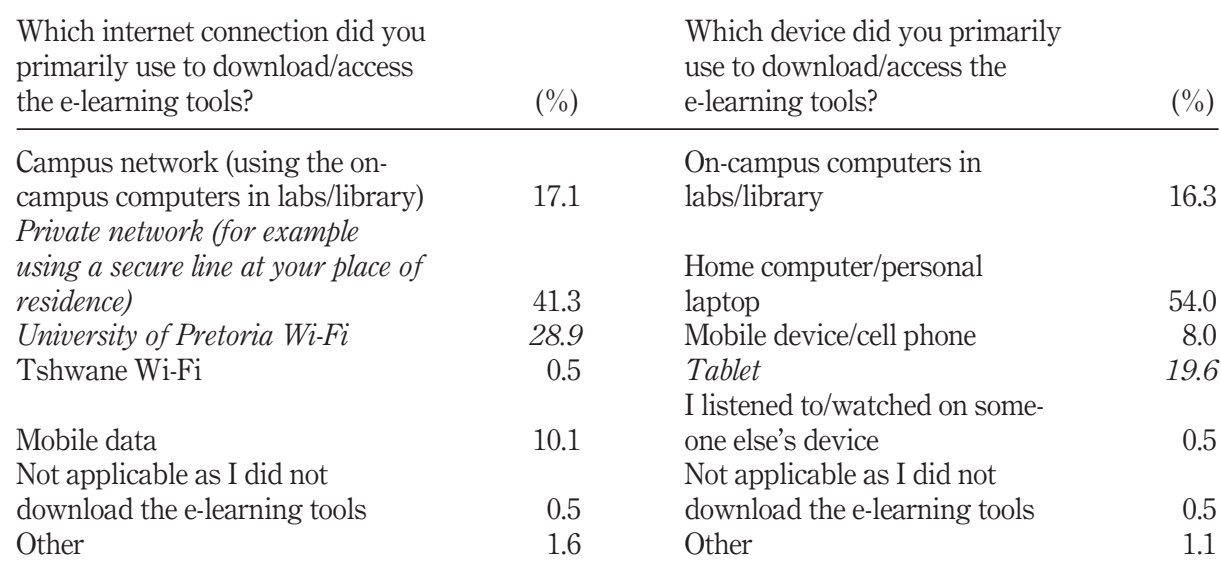

- Table V: Description of dependent and independent variables used as part of the regression analysis.

- Table VI: The results of the regression analysis for the revision (supplementary) e-learning tools using the variables as described in Table V.

- Table VII: The results of the regression analysis for the preparation (substitutional) e-learning tools using the variables as described in Table V.

A total of 1,048 students are enrolled for the course and were exposed to the e-learning tools. The survey was completed by 387 students, representing a response rate of 37 per cent. This was the response rate after several announcement reminders made by the researchers via the learning management system. Completion of the survey was entirely voluntary. According to Kelley et al. (2003), a response rate of 30 per cent is acceptable as an average response rate when compiling online surveys. The researchers acknowledge that the results of this study might not be used to make general assumptions of the whole study population, due to a risk of a non-response bias. In an attempt to address the non-response bias, Table II illustrates the demographics of the total group of students compared to that of the respondents.

Based upon the demographic information, the respondents appear to be representative of the total group of students. The response rate has been accepted by the researchers, as it appears as if the non-response bias risk is low.

Tables III and IV indicate a descriptive analysis of the data obtained towards meeting the first research objective:

To determine how students use and experience basic e-learning tools implemented into the undergraduate taxation curriculum.

The researchers have selected to report on the major themes for each qualitative response as analysed in Atlas Ti. Table III illustrates which primary internet connections and devices were used by students to access the basic e-learning tools:

It appears as if most of the students have access to data and devices. This is relevant in the South African context where technology availability is sometimes seen as a barrier for incorporation of ICT in the curriculum (Mugwanya et al., 2011). 
Table IV.

\begin{tabular}{|c|c|c|c|c|}
\hline Options & $\begin{array}{c}\text { Revision podcast } \\
(\%)\end{array}$ & $\begin{array}{l}\text { Preparation } \\
\text { podcast (\%) }\end{array}$ & $\begin{array}{l}\text { Preparation } \\
\text { vodcast }(\%)\end{array}$ & $\begin{array}{r}\text { Preparatio } \\
\text { VOP }(\%)\end{array}$ \\
\hline \multicolumn{5}{|c|}{ Amount of times that the students listened tollooked at the various e-learning tools (used as independent variables of interest-refer Table V) } \\
\hline Not once & 15.6 & 6.0 & 8.0 & 10.3 \\
\hline Once & 30.8 & 36.0 & 39.0 & 39.5 \\
\hline Twice & 29.8 & 33.0 & 28.9 & 30.8 \\
\hline Three times & 11.5 & 12.0 & 10.4 & 10.4 \\
\hline More than three times & 12.3 & 13.0 & 13.7 & 9.0 \\
\hline
\end{tabular}

If you did not listen to the specific e-learning tool, please tell us why not? (Students were allowed to select more than one option)

No response

Not applicable as I listened to all of the specific e-learning tools

I did not have internet access/access to data

I experienced difficulty downloading/opening the files

I had time constraints before the test (revision) or class (pre-work)

I did not want to/did not think it was necessary

Other: The quantitative data were analysed, and the top

themes identified are reported here

\begin{tabular}{cr} 
t. (Students were allowed to select more than one option) \\
6.2 & 7.5 \\
64.6 & 77.9 \\
1.7 & 1.5 \\
5.0 & 5.0 \\
& \\
11.9 & 6.2 \\
4.0 & 0.7 \\
6.6 & 1.2 \\
Not aware of its & Data constraints \\
existence & Tools not compatible with I-pa \\
\multicolumn{3}{c}{} \\
46.8 & Files were too large \\
33.3 & \multicolumn{2}{c}{59.4} \\
4.4 & 27.1 \\
2.6 & 3.1 \\
4.4 & 2.1 \\
8.5 & 5.2 \\
& \\
&
\end{tabular}




\begin{tabular}{lcccc} 
& Revision podcast & Preparation & Preparation & Preparation \\
Options & $(\%)$ & podcast $(\%)$ & vodcast $(\%)$ & VOP $(\%)$ \\
\hline
\end{tabular}

Preparation e-learning tools are better than preparations by means of textbook reading

I strongly agree

N/A

57.6

23.0

I agree to an extent

I do not agree/disagree

I disagree to an extent

I strongly disagree

N/A as I did not listen to the e-learning tools

In an ideal world, all my classes will be presented making use of preparation e-learning tools

I strongly agree

I agree to an extent

$$
\begin{aligned}
& 5.9 \\
& 5.2 \\
& 5.9 \\
& 2.3
\end{aligned}
$$

I do not agree/disagre

I disagree to an extent

I strongly disagree

N/A as I did not listen to the e-learning tools

Type of basic e-learning tool, preference

Vodcast

Voice Over PowerPoint

Podcasts

Timing of implementation preference

After a Learning Area, as revision

Before a Learning Area, as preparation
N/A

38.0

8.8

12.7

10.6

1.8

$41.9 \%$ first choice, $30.5 \%$ second choice, $26.4 \%$ third choice, $1.2 \%$ no response $34.6 \%$ first choice, $35.4 \%$ second choice, $28.8 \%$ third choice, $1.2 \%$ no response $22.2 \%$ first choice, $32.8 \%$ second choice, $43.8 \%$ third choice, $1.2 \%$ no response 
Table V.

\begin{tabular}{|c|c|c|c|c|}
\hline Variable & Variable explanation & Variable option & Respondents $N$ & Group $N$ \\
\hline \multicolumn{5}{|l|}{ Dependent variables } \\
\hline T_Q1 & Topic covered: Section 11(a) of the Income Tax Act & Mean & $62.3 \%$ & $60.0 \%$ \\
\hline Student mark for Question 1 of Test & $\begin{array}{l}\text { Independent variable of interest: } \\
\text { RevisionPodcast_11(a) }\end{array}$ & Standard deviation & 19.5 & 17.5 \\
\hline T_Q2 & Topic covered: Section 20A of the Income Tax Act & Mean & $65.3 \%$ & $58.0 \%$ \\
\hline Student mark for Question 2 of Test & $\begin{array}{l}\text { Independent variable of } \\
\text { interest:RevisionPodcast_20A }\end{array}$ & Standard deviation & 29.7 & 32.8 \\
\hline T_Q3 & $\begin{array}{l}\text { Topics covered: Capital allowances, Sections 11(o) } \\
\text { and 8(4)(a) and Section } 23 \mathrm{H} \text { of the Income Tax Act }\end{array}$ & Mean & $58.7 \%$ & $57.0 \%$ \\
\hline Student mark for Question 3 of Test & $\begin{array}{l}\text { Independent variable of } \\
\text { interest:RevisionPodcast_CA }\end{array}$ & Standard deviation & 19.1 & 17.3 \\
\hline CT_PreTools & $\begin{array}{l}\text { The class test was written at the beginning of the } \\
\text { session after students were exposed to the } \\
\text { preparation e-learning tools }\end{array}$ & Mean & $61.64 \%$ & $59.0 \%$ \\
\hline Student mark for Class Test & $\begin{array}{l}\text { Independent variable of } \\
\text { interest:PreTools_Combined }\end{array}$ & Standard deviation & 21.2 & 25.9 \\
\hline \multicolumn{5}{|l|}{ Independent variables of interest } \\
\hline RevisionPodcast_11(a) & \multicolumn{4}{|c|}{$\begin{array}{l}\text { A podcast relating to Section 11(a) was created (Table I). Students were asked whether and how many times they listened to the specific } \\
\text { podcast (Table IV) }\end{array}$} \\
\hline RevisionPodcast_20A & \multicolumn{4}{|c|}{$\begin{array}{l}\text { A podcast relating to Section } 20 \mathrm{~A} \text { was created (Table I). Students were asked whether and how many times they listened to the specific } \\
\text { podcast (Table IV) }\end{array}$} \\
\hline RevisionPodcast_CA & \multicolumn{4}{|c|}{$\begin{array}{l}\text { Podcasts relating to capital allowances and Section } 23 \mathrm{H} \text { was created (Table I). Students were asked whether and how many times they listened } \\
\text { to the specific podcast (Table IV) }\end{array}$} \\
\hline PreTools_Combined & \multicolumn{4}{|c|}{ Students were asked whether and how many times they listened to the specific e-learning tools (Table IV) } \\
\hline \multicolumn{5}{|l|}{ Control variables } \\
\hline \multirow[t]{2}{*}{ Aptitude } & \multirow[t]{2}{*}{ Mark of previous test used as proxy } & Mean & $55.3 \%$ & $49.3 \%$ \\
\hline & & Standard deviation & 15.6 & 17.2 \\
\hline \multirow[t]{2}{*}{ Engagement } & Continuous assessment mark (for example & Mean & $70.7 \%$ & $59.9 \%$ \\
\hline & $\begin{array}{l}\text { homework, class work etc.) used as proxy for } \\
\text { student engagement }\end{array}$ & Standard deviation & 15.2 & 22.1 \\
\hline
\end{tabular}




\begin{tabular}{|c|c|c|c|c|}
\hline Variable & Variable explanation & Variable option & Respondents $N$ & Group $N$ \\
\hline \multirow[t]{5}{*}{ Interest in taxation discipline } & \multirow[t]{5}{*}{ I find taxation as a discipline interesting } & I strongly agree & $39.8 \%$ & \multirow[t]{5}{*}{ N/A } \\
\hline & & I agree to an extent & $49.1 \%$ & \\
\hline & & I do not agree/disagree & $4.1 \%$ & \\
\hline & & I disagree to an extent & $3.4 \%$ & \\
\hline & & I strongly disagree & $3.5 \%$ & \\
\hline \multirow[t]{5}{*}{ Value of subject } & \multirow{5}{*}{$\begin{array}{l}\text { I am of the opinion that this subject will make a } \\
\text { significant contribution towards my future }\end{array}$} & I strongly agree & $66.9 \%$ & \multirow[t]{5}{*}{ N/A } \\
\hline & & I agree to an extent & $25.1 \%$ & \\
\hline & & I do not agree/disagree & $1.3 \%$ & \\
\hline & & I disagree to an extent & $1.3 \%$ & \\
\hline & & I strongly disagree & $4.4 \%$ & \\
\hline \multirow[t]{4}{*}{ Level of attention } & \multirow{4}{*}{$\begin{array}{l}\text { On average, with what level of } \\
\text { attention/concentration did you listen to the e- } \\
\text { learning tools }\end{array}$} & N/A as I did not download the e-learning tools & $1.0 \%$ & \multirow[t]{4}{*}{ N/A } \\
\hline & & Limited attention/concentration & $8.5 \%$ & \\
\hline & & Attention/concentration to some extent & $21.7 \%$ & \\
\hline & & Full Attention/concentration & $68.7 \%$ & \\
\hline
\end{tabular}


Table VI.

\begin{tabular}{|c|c|c|c|c|c|c|}
\hline \multirow{2}{*}{$\begin{array}{l}\text { Dependent variable } \\
\text { Independent/Control variable }\end{array}$} & \multicolumn{3}{|c|}{ T_Q1 } & \multicolumn{3}{|c|}{ T_Q2 } \\
\hline & Model 1 & Model 2 & Model 3 & Model 1 & Model 2 & Model 3 \\
\hline RevisionPodcast_11(a) & $0.067 *(-1.837)$ & $0.248(-1.156)$ & $0.457(-0.744)$ & & & \\
\hline RevisionPodcast_20A & & & & $0.462(0.737)$ & $0.094 *(1.678)$ & $0.062 *(1.873)$ \\
\hline Tax interesting & $0.002^{* * *}(3.149)$ & $0.020 * *(2.336)$ & $0.022^{* *}(2.297)$ & $0.219(1.232)$ & $0.942(0.072)$ & $0.985(-0.018)$ \\
\hline Tax valuable & $0.539(0.615)$ & $0.473(-0.718)$ & $0.445(-0.765)$ & $0.178(1.350)$ & $0.724(0.354)$ & $0.666(0.433)$ \\
\hline Attention & & $0.357(0.922)$ & $0.509(0.661)$ & & $0.010 *(2.601)$ & $0.005^{* * *}(2.793)$ \\
\hline Student engagement & & $0.000^{* * *}(4.671)$ & $0.000^{* * *}(4.607)$ & & $0.010 *(2.579)$ & $0.060 *(1.890)$ \\
\hline Aptitude & & $0.000^{* * *}(6.334)$ & $0.000 * * *(5.756)$ & & $0.000 * * *(7.035)$ & $0.000 * * *(5.991)$ \\
\hline Gender & & & $0.736(0.338)$ & & & $0.098 *(-1.661)$ \\
\hline Language & & & $0.385(0.870)$ & & & $0.743(0.328)$ \\
\hline Repeat/First Time & & & $0.729(0.346)$ & & & $0.244(-1.166)$ \\
\hline Degree enrolment & & & $0.920(0.100)$ & & & $0.075^{*}(-1.783)$ \\
\hline Age & & & $0.833(-0.211)$ & & & $0.038 * *(-2.081)$ \\
\hline Race_African & & & $0.005^{* * *}(2.794)$ & & & $0.062 *(1.874)$ \\
\hline Race_Indian & & & $0.064 *(1.859)$ & & & $0.323(0.990)$ \\
\hline Race_White & & & $0.007 * * *(2.711)$ & & & $0.076 *(1.782)$ \\
\hline
\end{tabular}

Notes: Race_Coloured was used as the reference dummy variable; * *** and *** denote significance at a 10, 5 and $1 \%$ level, respectively, based on a two-tailed test. $T$-statistics are indicated in parentheses. All of the variables are defined in Tables II and V 
Table VII. Preparation e-learning tools regression analysis

\begin{tabular}{lccc}
$\begin{array}{l}\text { Dependent variable } \\
\text { Independent/control variable }\end{array}$ & Model 1 & \multicolumn{1}{c}{ CT_PreTools } & Model 2 \\
\hline PreparationTools_Combined & $0.138(1.485)$ & $0.840(-0.202)$ & $0.996(-0.005)$ \\
Tax interesting & $0.706(0.377)$ & $0.384(-0.871)$ & $0.355(-0.927)$ \\
Tax valuable & $0.056^{*}(1.918)$ & $0.378(0.883)$ & $0.329(0.977)$ \\
Attention & & $0.162(1.402)$ & $0.161(1.404)$ \\
Student engagement & $0.000^{* * *}(7.348)$ & $0.000^{* * *}(6.717)$ \\
Aptitude & $0.040^{* *}(2.061)$ & $0.103(1.636)$ \\
Gender & & $0.700(-0.386)$ \\
Language & & $0.079 *(-1.760)$ \\
Repeat/First Time & & $0.467(-0.728)$ \\
Degree enrolment & & $0.469(-0.724)$ \\
Age & & & $0.949(-0.064)$ \\
Race_African & & $0.209(-1.257)$ \\
Race_Indian & & $0.871(-0.162)$ \\
Race_White & & $0.514(-0.653)$
\end{tabular}

Notes: Race_Coloured was used as the reference dummy variable; *, ** and *** denote significance at a 10,5 and $1 \%$ level, respectively, based on a two-tailed test. $T$-statistics are indicated in parentheses. All of the variables are defined in Tables II and V

Table IV illustrates the number of times that the students listened to the various e-learning tools, their experiences as well as preferences relating to type and timing of tool.

Students were asked to provide additional comments relating to the revision podcasts and pre-tools. The top themes identified, relating to the revision podcasts were as follows:

- it's easier to prepare by means of the revision podcasts, than making use of the textbook;

- it assists students with identifying problem areas; and

- students experienced the tools to be very helpful.

The top themes relating to the preparation tools were as follows:

- students prefer the tools to be made available as preparation tools, rather than revision tools;

- the preparation tools increased students' overall understanding of the topic; and

- students experienced the tools to be very helpful.

Regarding the language in which the e-learning tools were made available, 75 per cent of Afrikaans students agreed that they would prefer the tools to be made available in their language of instruction. This preference was also strongly indicated in the qualitative feedback. Educators at universities with more than one language of instruction should take note of this preference.

The data indicate that students experienced the e-learning tools to be helpful study aids and that approximately two-thirds of the students listened to the various tools once or twice. The small amount of students who did not listen to the tools indicated that it 
was mostly due to time constraints. However, the themes identified in the qualitative feedback should be indicators to educators to focus upon explaining the tool availability, the download process (including file sizes), data availability as well as device compatibility. Students indicated a preference for the tools to have a visual component (synchronous), to include examples and to be made available as preparation (supplementary) rather than revision (substitutional) tools. Students prefer e-learning tools for class preparation, rather than reading through the textbook.

Table $\mathrm{V}$ illustrates the descriptive statistics of the dependent, independent and control variables which were used in the hierarchical regression analysis towards meeting the second research objective:

- to determine whether the use of basic e-learning tools has an impact on student performance.

The demographics as per Table II were also used as control variables. The researchers used proxys for factors that have an impact upon test performance. Where applicable, the factors for the group have also been included to address non-response bias.

Table VI describes the results of two of the regression analyses performed with the test marks as dependent variables (Table V) and the amount of times which student listened to the supplementary asynchronous e-learning tools (revision podcasts) as the variable of interest. Three models for each regression analysis are reported on, using an increased number of control variables in each subsequent model.

The regression analysis using the dependent variable "T_Q3" and the variable of interest "RevisionPodcast_CA" (Table V) is not reported, as the inferences are the same as those of the two regression analyses reported in Table VI. The student demographics as per Table II were included as Model 3 in the regression analyses.

Table VII describes the results of the regression analysis performed with the class test mark as the dependent variable (refer CT_PreTools in Table V) and the amount of times which students listened to the substitutional synchronous and asynchronous e-learning tools (preparation podcasts, vodcasts and voice-over-PowerPoint) as the variable of interest. An exploratory factor analysis was conducted on the independent variables of the different preparation e-learning tools, using principal axis factoring and promax rotation. The factor analysis was conducted to determine whether the five variables of interest comprising preparation e-learning tools (being three preparation podcasts, one preparation vodcast and one preparation voice-over-PowerPoint, refer Table I) form a unidimensional construct that is reliable so that a valid composite variable could be constructed. Using Cronbach alpha, the internal consistency (reliability) for the construct PreTools_Combined was found to be 0.913 . As this value is above the acknowledged threshold of 0.7 , it was deemed satisfactory.

From a review of Tables VI and VII, it is clear that the listening to the e-learning tools does not have a significant impact on test results (student performance) and may in fact even have a negative correlation with student performance, depending on the specific topic. However, if student engagement and aptitude is taken into account, the fact that students listened to the podcasts moves towards a more significant impact on student performance. Student demographics do also not appear to have a significant impact on student performance, with the exception of race that appears to have a significant impact in Table VI, relating to revision e-learning tools. However, the impact of race is not consistently significant. 
When interpreting the results of Tables VI and VII, it should be noted that it is difficult to isolate all factors that may have an effect on student performance in an uncontrolled environment. The finding that student engagement and aptitude has a more significant impact on student performance than whether students used the e-learning tools, is consistent with previous findings in literature (using experimental or quasi-experimental research) indicating that e-learning tools is not necessarily a superior medium to face-to-face instruction (USA Department of Education, 2009). Studies that show that blended learning is more effective than pure face-to-face learning indicate that the factors impacting student performance is a combination of the utilisation of blended learning as well as pedagogical changes to increase student engagement by meeting student demands for flexible learning (i.e. creating a student-centred learning environment) (USA Department of Education, 2009; Bayerlein, 2015). Therefore, although the utilisation of e-learning tools in itself does not always have a direct measurable impact on student performance (as was the case in this study), the environment created, if based on sound pedagogical principles, contributes on average to higher student performance than in the traditional face-to-face classroom (USA Department of Education, 2009; Garrison and Kanuka, 2004; Graham et al., 2013).

\section{Conclusion}

Educators in the broad accounting discipline, including taxation educators, are faced with the challenges to address the flexible learning needs of Millennial students (Howe and Strauss, 1991; Lai and Hong, 2015; Sandeen, 2008), to use "in class/contact time" effectively to meet the demands of professional bodies and future employers (SAICA, 2015; SAIT, 2015; Apostolou et al., 2013; Barac, 2009; Steinbank, 2010) and to decrease the transactional distance between educators and students in large classes (Gibbs and Jenkins, 1992; Van Rooyen, 2010; Bayerlein, 2014).

To address these challenges, educators should move to a student-centred approach to the facilitation of learning (Fink, 2003; Hesketh, 2011; Leveson, 2004). Educators should embed their pedagogical decision making in learning theories to create significant learning experiences for students (Slabbert et al., 2009). The accreditation requirements at South African Universities limit taxation educators to mostly make pedagogical decisions only about content delivery as a component of undergraduate taxation curricula (De Villiers and Venter, 2010).

The Blended Learning Theory has been advocated as a learning theory that can assist taxation educators to move to a student-centred approach to the facilitation of learning, to address the challenges they are confronted with (Garrison and Kanuka, 2004; Graham et al., 2013). Some of the advantages of the Blended Learning Theory are that it complies with the flexible learning needs of Millennial students (Aliotta et al., 2008; Dickfos et al., 2014); it opens up "in class/contact time" for effective facilitation of learning (Weil et al., 2014; Wong et al., 2014), and it assists to decrease the transactional distance between students and educators in large student groups (Chan and Lee, 2005).

The Blended Learning Theory can be implemented through the inclusion of basic e-learning tools into the undergraduate taxation curricula (Heilesen, 2010; Mugwanya et al., 2011). The development of basic e-learning tools such as podcasts, vodcasts and voice-over-PowerPoint as either substitutional or supplementary tools can assist educators with time, technological and budget constraints with a sustainable solution to 
the implementation of the Blended Learning Theory (Vogele and Gard, 2007; Weil et al., 2014).

This article describes the implementation of such basic e-learning tools using an action research methodology and aims to determine students' use and experience of the implemented tools, as well as whether the use of such tools have an impact upon student performance.

It appears as if most students have access to data and devices to support the implementation of e-learning tools into the curriculum. Students experience the tools to be helpful study aids that they would prefer as a constant addition to their learning material. Students prefer short, visual tools containing examples, in their language of instruction. Students prefer substitutional tools to supplementary tools, as having access to the tools before class assists them with an overview of the work and to identify problem areas. Students experience e-learning tools to be better for class preparation purposes than working through the textbook. When students did not listen to the tools, it was due to the fact that they experienced time constraints, were not aware of the tools or had trouble downloading the tools. It is suggested that educators include download instructions when making tools available. From the regression analysis, it appears as if the utilisation of the e-learning tools did not have an impact upon student performance. Student aptitude and student engagement are more significant predictors of student success. However, although there was no impact on performance, it does appear as if the students perceived an improvement in the learning environment. Previous studies have indicated that an increase in student engagement, where students take control for their own learning, may lead to an increase in student performance (USA Department of Education, 2009).

The need for flexible learning of the Millennial generation sitting in our classes today is a reality that educators should accept (Lai and Hong, 2015). Educators in the accounting and taxation discipline have been made aware of the need for changes in their curricula to meet various stakeholder demands (Boritz and Carnaghan, 2003; McWilliam, 2008; Miller and Woods, 2000; Apostolou et al., 2013). However, due to a limited amount of studies incorporating effective classroom tools to address educator challenges, and determining students' use and experience of various tools as well as whether such use has an impact on student performance, change has been slow. This article provides an example of how basic e-learning tools can be created and included in the taxation curriculum by educators with time, technological and budget constraints. It provides a sustainable way of moving towards a student-centred approach to the facilitation of learning, embedded in the pedagogical Theory of Blended Learning. The inclusion of e-learning tools into the curriculum may not have shown an effect upon student performance in this study, but it does create a learning environment that assists educators to use "in class/contact time" effectively, decrease transactional distance and address the flexible learning needs of the Millennial students. These benefits may assist educators, specifically those dealing with large classes and diverse student populations, to meet the demands of the various stakeholders more effectively.

The researchers acknowledge that there are various limitations to the study, due to the narrow scope of the research. There are many other possible learning theories that may address the challenges faced by accounting and taxation educators. The researchers mentioned some of these learning theories, but an investigation into all of the learning theories was not part of the scope of the study. There are also many possible 
e-learning tools which can be incorporated into a student-centred approach to the facilitation of learning embedded in Blended Learning Theory. The researchers chose to only implement podcasts, vodcasts's and voice-over-PowerPoint, but an area for future research may be to investigate other tools as well. The researchers also did not measure the effect of the incorporation of the e-learning tools upon the generic or soft skill development of the students. This may also be a valuable area for future research. To truly isolate the effect of the incorporation of e-learning tools into a curriculum, an experimental research design should be followed to control for elements that have an impact on student learning. This approach was not followed in this study, but it would be a valuable contribution to this field of research.

\section{References}

Aliotta, M., Bates, S., Brunton, K. and Stevens, A. (2008), "Podcasts and lectures", in Salmon, G. and Edirisingha, P. (Eds), Podcasting for Learning in Universities, Open University Press, Milton Keynes, pp. 33-42.

Apostolou, B., Dorminey, J.W., Hassel, J.E. and Watson, S.F. (2013), “Accounting education literature review (2010-2012)”, Journal of Accounting Education, Vol. 31 No. 2, pp. 107-161.

Barac, K. (2009), "South African training officers' perceptions of the knowledge and skills requirements of entry-level training accountants", Meditari Accountancy Research, Vol. 17 No. 2, pp. 19-46.

Bayerlein, L. (2014), "Students feedback preferences: how do students react to timely and automatically generated assessment feedback?", Assessment and Evaluation in Higher Education, Vol. 39 No. 8, pp. 916-931.

Bayerlein, L. (2015), "Curriculum innovation in undergraduate accounting degree programmes through 'Virtual Internships”, Education and Training, Vol. 57 No. 6, pp. 673-684.

Bennet, N. (1976), Teaching Styles and Student Progress, American Educational Research Association, Washington, DC.

Boritz, J.E. and Carnaghan, C.A. (2003), "Competency-based education and assessment for the accounting profession: a critical review", Canadian Accounting Perspective, Vol. 2 No. 1, pp. 7-42.

Bullen, M., Morgan, T. and Quayyum, A. (2001), "Digital learners in higher education: generation is not the issue", Canadian Journal of Learning and Technology, Vol. 37 No. 1, pp. 1-24.

Chan, A. and Lee, M.J.W. (2005), "An MP3 a day keeps the worries away: exploring the use of podcasting to address preconceptions and alleviate pre-class anxiety amongst undergraduate information technology students", in Spennemann, D.H.R. and Burr, L. (Eds), Good Practice in Practice, Proceedings of the Student Experience Conference, Charles Sturt University, Wagga Wagga, NSW, pp. 59-71.

Coetzee, S. and Oberholzer, R. (2009), "The tax knowledge of South African trainee accountants: a survey of the perceptions of training officers in public practice", Journal of Accounting Education, Vol. 18 No. 4, pp. 421-441.

De Lange, P., Jackling, B. and Gut, A. (2006), "Accounting graduates' perceptions of skills emphasis in undergraduate courses: an investigation from two Victoria universities", Accounting and Finance, Vol. 46 No. 3, pp. 365-386.

De Villiers, C. and Venter, E. (2010), "The influence of the accounting profession on the academy: a cautionary case study”, Meditari Accountancy Research, Vol. 26 No. 8, pp. 1246-1278.

De Wet, J.H. and Van Niekerk, M.C. (2001), "An innovative approach to accounting education at the first-year level”, Meditari Accountancy Research, Vol. 9, pp. 93-108. 
Dickfos, J., Cameron, C. and Hodgson, C. (2014), "Blended learning: making an impact on assessment and self-reflection in accounting education", Education and Training, Vol. 56 Nos 2/3, pp. 190-207.

Dixon, J., Belnap, C., Albrecht, C. and Lee, K. (2010), “The importance of soft skills”, Corporate Finance Review, Vol. 14 No. 6, pp. 35-38.

Doman, S. and Nienaber, G. (2012), "Taxation education: current views and preferences of South African employers", International Business and Economics Research Journal, Vol. 11 No. 8 , pp. 951-962.

Du Toit, P.H. (2009), An Action Research Approach to Monitoring One'S Professional Development as Manager, Foundation for Professional Development, Pretoria.

Fink, L.D. (2003), Creating Significant Learning Experiences, John Wiliey and Sons, San Francisco, CA.

Gammie, B., Gammie, E. and Cargill, E. (2002), "Personal skills development in the accounting curriculum”, Journal of Accounting Education, Vol. 11 No. 1, pp. 63-78.

Garrison, D.R. and Kanuka, H. (2004), "Blended learning: uncovering its transformative potential in higher education", Internet and Higher Education, Vol. 7, pp. 95-105.

Gibbs, G. and Jenkins, A. (1992), Teaching Large Classes in Higher Education, Routledge, Great Britain.

Graham, C.R., Woodfield, W. and Harrison, J.B. (2013), "A framework for institutional adoption and implementation of blended learning in higher education", The Internet and Higher Education, Vol. 18, pp. 4-14.

Gros, B., Garcia, L. and Escofet, A. (2012), "Beyond the net generation debate: a comparison of digital learners in face-to-face and virtual universities", International Review of Research in Open and Distance Learning, Vol. 13 No. 4, pp. 191-210.

Guthrie, J., Evans, E. and Burritt, R. (2014), "Australian accounting academics: challenges and possibilities", Meditari Accountancy Research, Vol. 22 No. 1, pp. 20-37.

Heilesen, S.B. (2010), "What is the academic efficiency of podcasting?", Computers and Education, Vol. 55 No. 3, pp. 1063-1068.

Hesketh, J.H. (2011), “Accounting academics' multiple challenges: issues-driven learning offers a way forward”, SA Journal of Accounting Research, Vol. 25 No. 1, pp. 1-34.

Hite, P. and Hasseldine, J. (2001), “A primer on tax education in the United States of America”, Journal of Accounting Education, Vol. 10 No. 1, pp. 3-13.

Howe, N. and Strauss, W. (1991), Generations: The History of America's Future, 1584 to 2069, William Morrow \& Company, New York, NY.

Howieson, B. (2003), "Accounting practices in the new millennium: is accounting education ready to meet the challenges?”, The British Accounting Review, Vol. 35 No. 2, pp. 69-103.

Johnson, D.W. and Johnson, R.T. (1990), "Using cooperative learning in mathematics", in Davidson, N. (Ed.), Cooperative Learning in Mathematics, Addison Wesley, San Francisco, CA, pp. 103-125.

Jones, M.S. and Duncan, W.A. (1995), "Educator's forum: teaching the introductory tax course: a new paradigm", JATA, Vol. 17 No. 1, pp. 95-103.

Kelley, K., Clark, B., Brown, V. and Sitzia, J. (2003), "Good practice in the conduct and reporting of survey research”, International Journal for Quality Healthcare, Vol. 15, pp. 261-266.

Kermis, G. and Kermis, M. (2010), "Professional presence and soft skills: a role for accounting", Education Journal of Instructional Pedagogies, Vol. 2, pp. 1-10. 
Kolb, A.Y. and Kolb, D.A. (2005), "Learning styles and learning spaces: enhancing experiential learning in higher education", Academy of Management Learning and Education Kune 1, Vol. 4 No. 2, pp. 193-212.

Lai, K. and Hong, K. (2015), "Technology use and learning characteristics of students in higher education: do generational differences exist?”, British Journal of Educational Technology, Vol. 46 No. 4, pp. 725-738.

Laurillard, D. (2002), Rethinking University Teaching: A Conversational Framework for the Effective Use of Technologies, 2nd ed., Routledge Falmer, New York, NY.

Leveson, L. (2004), "Encouraging better learning through better teaching: a study of approaches to teaching in accounting", Accounting Education, Vol. 13 No. 4, pp. 529-548.

McCarthy, J. (2010), "Blended learning environments: using social networking sites to enhance the first year experience”, Australasian Journal of Educational Technology, Vol. 26 No. 6, pp. 729-740.

McCarthy, P.R. and McCarthy, H.M. (2006), "When case studies are not enough: integrating experiential learning into business curricula", Journal of Education for Business, Vol. 81 No. 4, pp. 201-204.

McNiff, J. and Whitehead, J. (2006), All You Need to Know About Action Research, Sage Publications, London.

McWilliam, E. (2008), "Unlearning how to teach", Innovations in Education and Teaching International, Vol. 45 No. 3, pp. 263-269.

Miller, A.M. and Woods, C.M. (2000), "Undergraduate tax education: a comparison of educators' and employers' perceptions in the UK", Journal of Accounting Education, Vol. 9 No. 3, pp. 223-241.

Mugwanya, R., Marsden, G. and Boateng, R. (2011), "A preliminary study of podcasting in developing higher education institutions: a South African case", Journal of Systems and Information Technology, Vol. 13 No. 3, pp. 268-285.

Prensky, M. (2001), "Digital natives, digital immigrants Part 1", On the Horizon, Vol. 9 No. 5, pp. 1-6.

Prinsloo, P. and Van Rooyen, A.A. (2007), "Exploring a blended learning approach to improving students' success in the teaching of second year accounting", Meditari Accountancy Research, Vol. 15 No. 1, pp. 51-69.

Sandeen, C. (2008), "Boomers, Xers and Millennials: who are they and what do they really want from continuing higher education?”, Continuing Higher Education Review, Vol. 78, pp. 11-31.

Slabbert, J.A., De Kock, D.M. and Hattingh, A. (2009), The Brave "New" World of Education: Creating a Unique Professionalism, Juta and Company, Cape Town.

Somekh, B. and Zeichner, K. (2009), "Action research for educational reform: remodelling action research theories and practices in local contexts”, Educational Action Research, Vol. 17 No. 1, pp. 5-21.

South African Institute of Chartered Accountants (SAICA) (2015), "Competency framework", available at: www.saica.co.za/Portals/0/LearnersStudents/documents/Competency_ framework_updated_2014_summary.pdf (accessed 14 January 2015).

South African Institute of Tax Practitioners (SAIT) (2015), “The tax professional qualification curriculum: knowledge component" available at: http://c.ymcdn.com/sites/www.thesait. org.za/resource/resmgr/Education_2014/TP_Curriculum_Knowledge_Comp.pdf (accessed 14 January 2015). 
Spector, J.M., Merrill, M.D., Ellen, J. and Bishop, M.J. (2014), Handbook of Research on Educational Communications and Technology, Springer, New York, NY.

Steinbank, L.J. (2010), "Students' perceptions of the usefulness of an accounting project in acquiring knowledge and professional skills", SAJAR, Vol. 24 No. 1, pp. 79-100.

Talebian, S., Mohammadi, H.M. and Rezvanfar, A. (2014), "Information and Communication Technology (ICT) in higher education: advantages, disadvantages, conveniences and limitations of applying E-Learning to agricultural students in Iran”, Social and Behavioural Science, Vol. 152, pp. 300-305.

Tynan, B. and Colban, S. (2006), "Podcasting, learner learning and expectations", Who's Learning? Whose Technology?, Proceedings of the 23rd Annual Ascilite Conference in Sydney, The University of Sydney, pp. 825-832.

Universum (2014), “Universum student survey 2013/2014”, University Report, South African Edition, available at: www.tut.ac.za/Other/heds/coop_edu/Research/Documents/2014\%20 TUT\%20SASS\%202013_2014\%20University\%20Report.pdf (accessed 15 July 2015).

USA Department of Education (2009), "Evaluation of evidence-based practices in online learning: A Meta-Analysis and review of online learning studies", Office of Planning, Evaluation and Policy Development, Washington, DC, available at: www.ed.gov/about/offices/list/opepd/ ppss.reports.html

Van Rooyen, A.A. (2010), "Effective integration of SMS communication into a distance education accounting module", Meditari Accountancy Research, Vol. 18 No. 1, pp. 47-57.

Visser, S., McChlery, S. and Vreken, N. (2006), "Teaching styles versus learning styles in the accounting sciences in the United Kingdom and South Africa: a comparative analysis", Meditari Accountancy Research, Vol. 14 No. 2, pp. 97-112.

Vogele, C. and Gard, E.T. (2006), "Podcasting for corporations and universities: look before you leap”, Journal of Internet Law, Vol. 10 No. 4, pp. 3-13.

Von Glasersfeld, E. (2001), "Radical constructivism and teaching", Prospects, Vol. 31 No. 2, pp. 161-173.

Weil, S., Da Silva, T. and Ward, M. (2014), "Blended learning in accounting: a New Zealand case", Meditari Accounting Research, Vol. 22 No. 2, pp. 224-224.

Wong, L., Tatnall, A. and Burgess, S. (2014), "A framework for investigating blended learning effectiveness”, Education and Training, Vol. 56 Nos 2/3, pp. 233-251. 